3-2021

\title{
Terror Threat at Tokyo Olympics 2021
}

Daiju Wada

Seiwa University

Follow this and additional works at: https://gensoken.toyo.ac.jp/japanese-society-and-culture

Part of the Other International and Area Studies Commons

\section{Recommended Citation}

Wada, Daiju (2021) "Terror Threat at Tokyo Olympics 2021," Japanese Society and Culture: Vol. 3 , Article 3.

DOI: $10.52882 / 2434-1738-0303$

Available at: https://gensoken.toyo.ac.jp/japanese-society-and-culture/vol3/iss $1 / 3$

This Article is brought to you for free and open access by Institute of Social Sciences. It has been accepted for inclusion in Japanese Society and Culture by an authorized editor of Institute of Social Sciences. 


\title{
Terror Threat at Tokyo Olympics 2021
}

Daiju Wada *

\begin{abstract}
While we witnessed collapse of Islamic State's territorial control, Jihadists threat will continue for decades. But the real threat will not come from groups such as Al Qaeda and Islamic State but its Salafi Jihadism. Of course, the ideological threat is not visible and can never be eradicated by military actions. Cyberspace has facilitated the threat to be transnational pandemic phenomenon, as proved by inspired individuals. The backgrounds of those vary by person and this ideology performs as a detonator in driving individuals into violent terrorists.

Japan is located at the periphery of Jihadist's interest. But Islamic State declared their intention to target Japan and included it in part of East Asia Wilayah before. While Japan has no serious confrontations surrounding Muslims, this ideological threat with internet deeper penetration has potential risk to emerge anywhere in the world. Including the fact that the Olympics continue to be a target or good opportunity for terrorists, Japan needs to develop counter-terrorism measures with the most sophisticated technology and awareness for crisis management.

After personal evaluation on post-IS world with Al Qaeda, this paper looks back history of terrorism in world events focusing on the Olympic games, and then shows the linkage between Japan and Jihadists. Finally, the paper analyzes possibility on Jihadist attacks targeting Tokyo Olympics 2021.
\end{abstract}

Keywords: Terrorism, Japan, Olympic, Jihadist, Security

Salafi Jihadism continues

Collapse of territorial governance and control by Islamic State was achieved. Nevertheless, it is uncertain that the collapse leads to the decline of Salafi Jihadism¹. Probably, it partially depends on its brand and ideology. Within 2 years after Islamic State's leader Abu Bakr al-Baghdadi declared the caliphate, they could succeed in making its affiliated groups, such as Wilayah Sinai and Wilayah West Africa, in many parts of the world and becoming leading group which has more influence than Al Qaeda in Jihadists at that time. But now, it seems that the territorial collapse leaded to decline its brand and influence. For example, Abu Muhammad al-Adnani's emphasis on lone wolf attacks in the $\mathrm{West}^{2}$, which is superficially the same with $\mathrm{Al}$ Qaeda's far enemy strategy, and change from Dabiq to Rumiyah just before its loss of town Dabiq in Syria suggest their predictability to decline physically in some day. It is also

\footnotetext{
※Lecturer Seiwa University

1 “The Terrorist Threat Is Not Finished", Russell E. Travers, Foreign Affairs, August 21, 2020.

2 "ISIS'S GLOBAL MESSAGING STRATEGY FACT SHEET", Jessica Lewis McFate and Harleen Gambhir With Evan\#Sterling, Institute for the Study of War (ISW), December 2014.
} 
conceivable that their predictability promoted their intention to make impactful brand of Islamic State in Jihadists, which is often called as cyber caliphate. But after all, the brand is uncertain to continue.

On the other hand, as the decline of Islamic State became significant, more attention has been paid to Al Qaeda again. Osama bin Laden's sun Hamza had been gradually emerging with video messages since 2015. In the messages, he emphasized to target the West, especially U.S and Israel, as his father often did before. He seemed to have an invariable charisma as Osama's sun and ongoing leader Ayman Zawahiri recognized him as best successor. Furthermore, contrary to Zawahiri, Hamza had never complained about Islamic State and al-Baghdadi and this made us felt that Islamic State and Al Qaeda try to compromise. While United State declared that Hamza was killed in Afghanistan-Pakistan border in September 2019, the UN Security Council Monitoring Team reported that between 400-600 Al Qaeda members are active in 12 Afghanistan provinces and maintains close contact with the Haqqani Network 3 . The both of Islamic State and Al Qaeda have the same ideology and goal, while differences are seen in strategic approaches for building up Islamic caliphate, such as whether to attack Shia Muslim.

For the future, three different scenarios are conceivable. The first is continuation of this discord. This is the most realistic and will likely continue. This scenario came from personal quarrel between Baghdadi and Zawahiri. The second is cooperation, which also means joint struggle against their enemy. This scenario means they would take a partnership in certain degree even though they fight separately. After the loss of territorial control, this may be more necessary strategy for Islamic State to survive. Islamic State has declared their allegiance to Osama bin Laden and a successor of Hamza or Zawahiri may strategically accept Islamic State's rapprochement for Jihadist survival. The third is their merger. Terrorism expert Dr. Bilveer Singh described this as "mega-jihadist grouping"4. The merger means that Al Qaeda and Islamic State including their affiliate groups will be absorbed into a one group and an overwhelming enormous group emerges. It is uncertain if Al Qaeda absorb Islamic State or vice versa. This scenario is the most unrealistic now, but we need to know that the vogue of Salafi Jihadism ideology will likely continue for foreseeable future.

\section{World Events and Terrorism ${ }^{5}$}

The world has faced different kinds of terrorism. But as Salafi Jihadism has preceding world attention in the last two decades, this kind of terrorism has been reported in recent Olympics history. While the history shows that Olympics is good opportunity for terrorists, they have targeted or used other events such as G7 Summit, Soccer World Cup and the Novel Prize Award Ceremony. The following table explains the detail.

July 2005: Gleneagles Summit

During the Summit, explosions occurred in subways and bus stop bringing 56 deaths. The perpetrators were four British Pakistanis.

August 2008: Beijing Olympics

Just before the Olympics, 21 July, buses suddenly exploded in Kunming, bringing three deaths and 13

3 Letter dated 19 May 2020 from the Chair of the Security Council Committee established pursuant to resolution 1988 (2011) addressed to the President of the Security Council”, the UN Security Council, 27 May 2020.

4 The Jihadist Threat in Southeast Asia: An Al Qaeda and IS-centric Architecture?”, RSIS Commentary, S. Rajaratnam School of International Studies, Nanyang Technological University, Bilveer Singh, 8 February 2017.

5 I referred to the following sites. National Consortium for the Study of Terrorism and Response to Terrorism (START) https://www.start.umd.edu/ 
injured. Eastern Turkistan Islamic Movement (ETIM) was thought to claim the responsibility. July 2010: South Africa Soccer World Cup

During the final game Spain vs Netherland, explosions targeting people who were enjoying the game at public space occurred. 64 people died and $\mathrm{Al}$ Shabaab declared the responsibility.

December 2010: Novel Prize Award Ceremony

Suicide bomb attack occurred near the ceremony venue, the perpetrator who was Iraqi Swedish only died.

August 2012: London Olympics

During the Olympics, suspects linked Al Qaeda who were 2 Chechen Russians and 1 Turk, tried to attack busy shopping mall in Gibraltar, Spain.

February 2014: Sochi Olympics

Before the Olympic during October to December in 2013, several attacks targeting train stations and buses occurred in Volgograd near Sochi. After the December attack, Caucasus Emirate claimed responsibility and threatened the Olympics.

August 2016: Rio de Janeiro Olympics

Just before the Olympics, police arrested 12 Brazilian young men to plan attacks during the Olympics. The suspects were thought to be inspired by Islamic State.

Historical linkage between Japan and Jihadists 6

Japan has never invaded countries in the Middle East and their relations is without problems today. Nevertheless, a number of Japanese victims have dramatically increased in recent years. The linkage seems thin but history shows us below. Some Al Qaeda members had stayed in Japan and some Japanese were said to be stimulated by Islamic State's brand.

1987: Khalid Sheikh Mohammed, who was Al Qaeda No.3, had stayed Shizuoka Prefecture near Tokyo for three months, undergoing training in rock-boring equipment.

December 1994: The bomb exploded aboard Philippines Airlines Flight 434, killing Japanese passenger as the Boeing 747 flew from Cebu to Tokyo. The perpetrator was Ramzī Yūsuf.

September 2001: 24 Japanese were killed in 9/11 attacks.

October 2002: 2 Japanese were killed in Bali nightclub attack. Jemaah Islamiyah claimed the responsibility.

2003 - 2004: Lionel Dumont had stayed in Niigata Prefecture totally for 9 months. He used a fake passport 4 times to enter Japan.

October 2003: Al Qaeda leader issued statement that Japan is the one of their targets.

November 2003: 2 Japanese diplomats were killed near Kirkuk, Iraq.

March 2004: After the train bombing in Madrid, Al Qaeda issued its responsibility and targeted Japan as well as Western countries.

December 2004: 24 years old Japanese man who was beheaded by Al Qaeda in Iraq (AQI) while touring in Iraq

April 2008: Ayman Zawahiri issued a statement that Japan is also our target because of its alliance with

6 Ibid. 
the U.S.

November 2008: Japanese worker was killed in Mumbai attacks. Lashkar-e Tayyaba is thought to be behind the attacks.

January 2013: 10 Japanese workers were killed in In Amenas, Algeria, gas plant attack. Belmokhtar

Brigade linked with $\mathrm{Al}$ Qaeda in Islamic Maghreb (AQIM) claimed the responsibility.

January 2015: 2 Japanese men were beheaded by British Islamic State member “Jihadi John” in Syria.

March 2015: 3 Japanese tourists were killed at Bardo Museum in Tunisia. Militants tied Islamic State trained in Libya were behind the attack.

July 2016: 7 Japanese aid workers belonging to JICA were killed in Dhaka, Bangladesh. The militants of Neo-Jamaat-ul-Mujahideen Bangladesh (Neo JMB) linked with Islamic State claimed the responsibility.

Possibility on Jihadist Attacks at Tokyo Olympics 2021

Considering on the above, while the Jihadist threat will likely continue, it may be low possibility that there would be terror attacks by Jihadists during the Olympics. Why the author predicts so comes from Japan's internal factors.

First is environment surrounding Muslims in Japan. Its population in Japan is thought to be approximately 100 thousands and that rate is less than $0,1 \%$ in the total population. Then, the Muslim has faced no serious structural discriminations from domestic society, such as often seen in European countries in recent years, and the rage or frustration will not likely to rise. Instead of that, Japan has historic dispute with China and Koreas and those related terrorism seems more realistic.

The second is Jihadist's interest. While Islamic State has declared Japan as their target before, its higher priority is to attack the West and authoritarian regimes in Arab world. Japan is mostly

positioned in the periphery for Jihadists. While they frequently threaten countries through online messages as fanatic, they think profoundly and act strategically. From the past, even if Tokyo is included in their target list, they know its difficulty from the facts above.

Therefore, the past cases indicate that it is more precise to understand that Japanese casualties were mostly "involved" rather than directly "targeted". That suggests that jihadists are not always regarding Japan as prime target.

The third is Japan's technological sophistication on counter terrorism. Not only the fact that seas prevent terrorists from entering Japan easily, Japanese people have struggled to develop the capacity for the Olympics. Internationally, Japan has been cooperating with countries in making related treaties more efficient and leading socio-economic efforts to eradicate poverty, unemployment and discrimination. Domestically, especially after 9.11, Japan has tightened and developed aviation security. In recent years, Japan has decided positively to innovate latest technologies such as Full Body CT Scan and Face Recognition System, as the number of foreign visitors dramatically increasing.

These factors limit Jihadist's motivation to target the Olympics. But the quality of this transnational and franchised terrorism has another aspect. As mentioned above, Jihadist threat has spread via cyberspace and that ideology or brand is resilient. Internet deeper penetration into countries can easily connect terrorist and individual and it is problem for any country if radicalized ones rise till the Olympics. Japan should not look away from this reality.

Japanese media reminds that 2 Japanese young men, who were 26 years old from Hokkaido 
University and 23 years old from Wakayama Prefecture near Osaka, tried to visit Syria to join IS. Why they tried to join is not still revealed. But even if they have nothing to do with Islam, recent studies suggest it is undeniable that losing sense of belongings, despair, social frustration or adventurism connects with Islamic violent extremism. To be precise, Al Qaeda and IS as brand or ideology have been efficient like detonator to make people violator, though the degree of radicalization may differ by person. For example, as the world knows, while freedom of cyber access is guaranteed in Japan, terrorists can also enjoy the freedom. However, contrary to that, social problems of young Japanese generation are not so known from the world. Compared to the older generation, their value has varied and diversified. In other word, the number of individualists has increased and they sometimes frustrate at working places, feeling generation gap from traditional collectivism. As the result, young Japanese tends to suffer from mental illness and social isolation and increase frustration. This reality does not differ from what has been occurring in the West.

Previous studies reveal that these general problems lead to frequent acts of terrorism which cars and knives are often used. This seems that terrorism is eroding into the domain of general crime which often occurs anywhere. These incidents have complicated to find a border between them and terrorism has become more routine.

Finally, though the above factors provide difficulty for Jihadists, this kind of routine terrorism will be one of the risks for Japan and it is quite difficult to prevent. It is likely that Japan cooperates more with the world to develop counter terrorism measures, but they need to know the risk of developed way of terrorism and take care of internal affairs such as socio-economic factors which Japan is facing today. 